\title{
Kente Kazandırılan Yeni Yaşam Alanları
}

\author{
Tolga Kayacan ${ }^{1 *}$, Yaprak Özel², Berna Kayacan ${ }^{3}$ \\ ${ }^{1}$ Şehir Plancisı, Dr. (ORCID: 0000-0003-0818-277X) \\ 2 İstanbul Gelișim Üniversitesi, Güzel Sanatlar Fakültesi, İç Mimarlık Bölümü, İstanbul, Türkiye (ORCID: 0000-0002-6439-4817) \\ 3 İstanbul Ticaret Üniversitesi, Mimarlık ve Tasarım Fakültesi, İç Mimarlık ve Çevre Tasarımı Bölümü, İstanbul, Türkiye (ORCID: 0000-0003-0941-486X)
}

(İlk Geliş Tarihi 3 Temmuz 2019 ve Kabul Tarihi 24 Temmuz 2019)

(DOI: $10.31590 /$ ejosat.592411)

ATIF/REFERENCE: Kayacan, T., Özel, Y. \& Kayacan, B. (2019). Kente Kazandırılan Yeni Yaşam Alanları. Avrupa Bilim ve Teknoloji Dergisi, (16), 679-687.

\begin{abstract}
$\ddot{O} \mathbf{z}$
Göçebe hayattan yerleşik hayata geçişte, ilk yerleşim yeri olarak ticaret veya tarım için en uygun koşulların olduğu bereketli, su kıyılarının tercih edildiği görülmektedir. Zaman içinde nüfus artmaya başlamış, yeni göçler ile bu artış desteklenmiştir. Şehirin biçimlenmesindeki ana etkenler; sanayileşme, yeni kurulan sirkülasyon ağları, ticaretteki artış oluşturmuştur. Sanayileşme ile kurulan fabrikalar, hava ve kara sikülasyon ağları gibi şehri diğer şehirler ile iletişime geçiren kamusal alanlar şehir hayatını aksatmayacak şekilde konumlanmıştır. Bazı şehirler ise kurulan fabrikaların yanında oluşmuş ve biçimlenmiştir. Tarım ile uğraşan toplumlar ise tarım arazileri ve ulaşım ağlarına yakın yerleri yerleşim için benimsemiş̧tir. Şehirler bu şartlara bağlı olarak giderek genişlemiş ve yayılmıştır. Ancak teknolojik gelişmeler, sanayileşme, seri üretim teknolojileri gibi değişiklikler, bunların yanı sıra fabrikaların oluşturdukları kirlilik ve atıklar, yer altı kaynaklarının tükenmesi gibi değişimler geniş metrekareler kaplayan bu yapıları ve alanları kullanım dışı bırakmıştır. Bunların yanı sıra şehrin yayılması ile birlikte öncesinde şehrin dışında yerleşmiş olan bazı geniş metrekareli fonksiyonlar artık şehrin içinde kalmıştır. Aktif olarak işlevini devam ettiren bu fonksiyonlar (fabrikalar, ulaşım binaları gibi) ise ihtiyaca bağlı olarak yapılması gereken kendi iç büyümelerindeki gelişimi sağlayamamakta ve konumları nedeniyle de şehir sirkülasyonunda negatif bir etki yaratmaktadır. İşlevini yitirmiş olanlar ise atıl ve terkedilmiş bir şekilde kendi kendini tüketmekte ve şehir içinde istenmeyen bir alan haline gelerek, güvenlik açısından sorunlar oluşturmaktadır. Bu çalışmada, öncesinde şehrin dışında konumlanan ancak gelişmelere bağlı olarak şehrin içinde kalmış geniş metrekarelere sahip işlevini yitirmiş atıl kalmış alanların yeniden işlevlendirilmesi üzerine çalışılmışırı. Yeniden işlevlendirilerek kentin ve kentlinin hayatına katılan bu alanların önceki fonksiyonları ve yeni fonksiyonlarının neler olduğu araştırılmıştır ve kentliye ve kente katkı sağlayabilmesi için yapılan çözümler ve yöntemler, yurtdışı örnekleri üzerinden incelenmiş̧ir. Sonuç olarak şehir merkezinde yeralan ve geniş metrekareler kaplayan, işlevsiz, mevcut bir alanın atıl halindenkurtarlıp yeniden yaşama aktarılması aşamasındaki ana etkenin ne olması gerektiği ortaya konmuştur. Sonuç bölümünde İstanbul kentindeki dönüşüm örnekleri irdelenmiştir.
\end{abstract}

Anahtar Kelimeler: Kent, Kamusal Alan, Tasarım.

\section{New Regained Living Spaces of the City}

\begin{abstract}
In the transition from nomadic life to settled life, it is seen that waterfronts are preferred as the first settlement for trade or agriculture.Over time, the population started to increase and increased with new migrations. The main factors in shaping the city; industrialization, newly established transportation routes, increased trade. Public spaces that connect the city with other cities, such as factories established by industrialization, air and land circulation routes, are positioned in a way that will not interfere with city life. Some cities are located next to the established factories.Communities engaged in agriculture have adopted areas close to agricultural land and transport networks for settlement. Depending on these conditions, cities have gradually developed and expanded. However, technological developments, industrialization, mass production technologies, pollution and wastes created by factories, changes such
\end{abstract}

\footnotetext{
*Sorumlu Yazar: Şehir Plancıs1, Dr. ORCID: 0000-0003-0818-277X, tolga_kayacan@yahoo.com
} 
as depletion of underground resources have left the buildings and areas covering these large square meters unusable. In addition, with the expansion of the city, some large square-meter functions, which had previously settled outside the city, are now in the city. These functions, which continue to function actively (such as factories, transportation buildings), cannot achieve the development of their own internal growth depending on the need and have a negative impact on the city circulation due to their location. Functions that cannot continue to function are self-depleted and abandoned and become an undesirable area in the city, causing problems in terms of security. In this study, it was aimed to reuse the idle areas which were previously located outside the city but have large square meters in the city due to the developments. By re-functionalization, the previous and new functions of these areas participating in the life of the city and the citizen have been investigated, solutions made to contribute to the citizens and the city were examined through examples from other cities. As a result, the main factor in the transfer of these areas in the city center from idle state to life has been revealed. In the conclusion part, some of the transformations in Istanbul are examined.

\section{Keywords: Urban, Public Space, Design.}

\section{Giriş}

Kentlerin kurulma sürecinde pek çok kent yaşamını destekleyen fonksiyon, kentin içinde meydanlarında ve yakın çevresinde (kenti besleyen fabrika, ulaşım binaları gibi) kent ile bağlantıları kurularak konumlanmaktadır. Kentlerin zaman içinde nüfus artışı gibi nedenlere bağlı olarak konut yerleşim ihtiyacının büyümesi ile birlikte, şehir genişlemekte büyümekte, özellikle geniş metrekarelere ihtiyaç duyan bazı fonksiyonlar (havaalanı, sanayi tesisleri, arıtma tesisleri, vb.) önceki yerleşimlerinde kent dışında veya yakın çevresinde kalırken artık şehrin merkez noktalarında kalmaya başlamışlardır. Kentin bu gelişimine bağlı olarak artan ihtiyaçlar da göz önünde bulundurulduğunda bu dış fonksiyonlar kendi içlerinde yetersiz kalabilmekte daha iyi hizmet sunabilmek amacı ile gelişmeye ve büyümeye ihtiyaç duymaktadır. Bu nedenle, şehir yerleşimi içinde kalan geniş metrekarelere sahip kenti besleyen ancak yeterli olamayan bu fonksiyonlar, kurulan şehir aşamasında dışarda ancak gelişime bağlı olarak içerde, şehir merkezinde, sıkışan alanlarını bırakarak şehir yerleşimi dışında kalacak yeni yerleşimlerine geçmektedirler. Bunun sonucu olarak şehrin merkez noktalarında atıl kalan geniş metrekareli alanlar oluşmaktadır. Bu işlevini yitirmiş alanların şehirle entegrasyonunun yeniden sağlanması ve kentliye kazandırılması gerekliliği ortaya çıkmaktadır.

Bu çalışmada kent içinde kalan bu atıl alanların farklı kültüreler ve yerleşimlerde kentliye nasıl kazandırıldığı örnekler üzerinden incelenmiştir. Şehirlerin gelişim süreçlerine bağlı olarak alanların önceki işlevleri, dönüşüm süreçleri ve yeni işlevleri ele alınmıştır. Kent yaşamı ve kültürel farklılıklar; kentin ve kentlinin ihtiyaçlarında farklılaşmaya neden olmaktadır. Örnekler üzerinde yapılan incelemelerde; bu alanların üzerinde bulunan mevcut yapılarından arındırılarak hizmet vereceği fonksiyonuna göre yeni yapılar inşa edilebildiği gibi, mevcut yapıları korunarak hizmet vereceği yeni fonksiyon hem alana hem mevcut yapılara yükleyerek de kent yaşamına entegre edildiği görülmektedir. Bazı alanlar ise tamamen temizlenerek kamusal açık alana dönüştürüldüğü görülmüştür.

\section{Materyal ve Metot}

\subsection{Kent ve Kentleşme}

Kent sözcüğü kavramsal olarak incelendiğinde; Orta Asya Türklerince Şehir karşılığı olarak kullanıldığı ortaya çıkmaktadır. Soğdça'dan Türklerin diline geçen "kend" sözcüğü yaygın olarak kullanılmış: "Yarkend", "Taşkend", "Semizkend" (Semerkant) örneklerinde olduğu gibi birçok büyük şehirler bu adlarla adlandırılmıştır (Baykara, 2002).

Soğdlar, Doğu İran kavimlerindendir ve zamanla Türklerin içine karışmışlardır. Eski Türklerde daha önceleri şehir kelimesi karşılığı olarak "Balık” kelimesi kullanılmaktadır. Balık kelimesinin günümüzde kullanılan "Balçık” kelimesi ile yakın ilgisi vardır. Çünkü eski Türk kentlerinde hâkim ve etkin unsur olan koruma amaçlı surlar balçıktan yapılmaktadır (Baykara, 2002).

Türk Dil Kurumu'na göre dilimize geçen şehir kelimesi de Farsça'da "şehr” kökeninden gelmektedir. Toplumumuzda Kent kavramı ile aynı anlamı ifade etmek üzere yaygın olarak kullanılmaktadır. Ayrıca Arapça'dan dilimize geçen "vilayet” kelimesi; merkezi yönetimin, coğrafya durumuna, ekonomik şartlara, kamu hizmetlerinin gereklerine göre, ülke üzerinde yayılmış, bir vali yönetimindeki en önemli bölümü, "il”" ile aynı anlamlıdır.

Bakış açısı değiştikçe kent tanımı da değişmektedir. Sosyologlar, tarihçiler, şehir plancılar, iktisatçılar, antropologlar, edebiyatçılar v.b. her bir disiplinin kendi kavrayışı üzerine bina edilmiş kent tanımı vardır. Nüfus büyüklüğü, idari statü, nüfusun yapısı, iş bölümü ve uzmanlaşma, örgütlenme biçimi, işlev alanlarındaki farklılaşma, iş gücünün sektörel dağılımı, heterojenlik, fiziksel doku, üretimin yapısı gibi ölçütler kullanılarak bu tanımlamalar yapılmaktadır (Dinçer, 1999).

Prehistorik dönemde, bir toplum olarak insan yerleşimleri ancak şu şartları yerine getirebilirse ayakta kalabilmekteydi: klan ya da toplum barınabiliyor ve kendilerini düşmanlardan ya da vahşi hayvanlardan koruyabiliyorsa; sadece günlük ihtiyacı karşılayacak kadar değil, diğer hasada kadar yeterli olacak depolayabilecekleri yiyecek yetiştirebiliyorsa (Adedeji, 2011).

Tarihi kayıtlara bakıldığında en eski yerleşim birimlerinin (belli aktivitelerin gerçekleşmesi; ticaretin yapılması gibi) ortaya çıkışı M.Ö. 6000-5000 yılları arasındadır. Eski yerleşim yerlerine göre gelişmiş sayılabilecek yerleşim yerlerinin ortaya çıkışı ise M.Ö. 4000 yılından itibarendir (Altuntaş, 1997). 
İlk kentlerin hangi şartlar ile oluştuğunu açıklamaya yetecek kadar delil olmamakla birlikte, bazı kuramcılar kentlerin oluşumunu açıklayabilecek bazı ön koşul ve temel mekanizmalardan bahsetmektedir. Tarımın kentlerin oluşumu için ön koşul olduğuna inanılmaktadır, kent fazla ürün için depolama imkânı sunmakta ve ölçek ekonomileri yaratmaktadır. Geleneksel görüş, kentlerin, tarımın yayılmasıyla birlikte Neolitik Devrim'den sonra gerçekleştiğini kabul etmektedir. Tarımın gelişmesi, avcı-toplayıcıların göçebe yaşam tarzını terk edip, tarımsal üretim yapan diğer insanların yanına yerleşmeye teşvik etmiştir. Tarım ile daha çok yiyecek elde edilmiş, bu da daha yoğun yerleşimleri olanaklı kılmıştır, yani kentsel gelişimi desteklemiştir. Tarım daha yoğun, yerleşik nüfusu getirmiş, depolama gerektiren üretim fazlası yiyecek de ticaretin başlamasını sağlamıştır. Bu koşullar kent yaşamının oluşması için önemli ön şartlar olarak görülmektedir (Url-1). Buradan hareketle kentlerin sulak ve verimli topraklarda ortaya çıktığı sonucuna varılabilmektedir.

İyi bir çevre ve güçlü sosyal organizasyon, başarılı bir kentin oluşumu için iki gerekliliktir. İyi bir çevre, temiz su kaynakları ve ürün yetiştirmek için uygun iklim koşullarını kapsamaktadır. Güçlü sosyal organizasyon ise, zor zamanlarda yeni oluşan kentin birlikte çalışmasını ve insanların kentin geleceği için çeşitli fonksiyonlar geliştirmesini (çiftçi, tüccar, vb.) sağlamaktadır (Url-1).

Sanayi devrimine kadar kentler, nüfus artış oranı çok düşük olan yaya kentleridir. Koruma amacıyla yapılan surlar içerisinde dar sokaklar ve kü̧̈ük parseller ile yoğun bir yapılaşma söz konusudur. Sokaklar insan ve hayvan ulaşımı amacıyla kullanılmaktadır. Kent içi mekânda depolama alanları haricinde herhangi bir ayrışma görülmemektedir. Binaların giriş katları iş yeri ya da üretim atölyesi, üst katları ise konut olarak kullanılmaktadır (Enlil, 2011).

Sanayi öncesi kentinin ekonomisinin diğer yönleri, onun kendine özgü üretim biçimiyle ilgilidir. İşlerde çok az farklılaşma ya da uzmanlaşma vardır. Zanaatkârlar kimi loncaların ve topluluk kurallarının sınırları içinde, genelde işlerini evlerine ya da yakınlardaki küçük bir dükkâna taşıyarak, çalışma koşulları ve üretim yöntemleri üzerinde doğrudan bir denetime sahip olarak, neredeyse üretim sürecinin her aşamasına katılırlar (Sjoberg, 2002).

\subsection{Sanayi Devriminin Etkileri}

18. yüzyılın ortalarından itibaren yeni enerji kaynaklarının keşfedilmesi ile birlikte üretim ve ulaşımda önemli değişiklikler gerçekleşmeye başlamıştır. Kömür ve buhar enerjisinin kullanımı ile birlikte tarımsal üretimde verim artmaya başlamış, üretilen yeni araç-gereçler ve makineler ile birlikte sanayileşmenin önü açılmıştır. Daha önce hayvan gücü ile sağlanan ulaşımda, özellikle buhar gücünün kullanılmaya başlamasıyla birlikte daha uzun mesafeler kat edilerek yeni hammaddelere ulaşım ve daha uzun mesafede ticaret yapılmasının önü açılmıştır. Tüm bu gelişmeler Sanayi Devrimi olarak bilinen dönemi başlatmıştır.

Geleneksel el üretiminden makine üretimine geçilmesi ile birlikte tüketim malları artmaya ve çeşitlenmeye başlamıştır. Üretimin artması iş bölümü ve uzmanlaşma gibi kavramları da ortaya çıkarmıştır. Bu da toplumsal yapının karmaşıklaşmasına sebep olmuştur. El emeğine dayanan üretim işlerinde çalışan mavi yakalılar ve daha çok zihinsel güç ile masa başında çalışan beyaz yakalılar ortaya çıkmıştır.

Üretimin artması ile birlikte fabrikalar kurulmaya başlanmıştır. Fabrikalar çeşitli kriterlere göre yer seçimini gerçekleştirmiştir. Bazı fabrikalar işgücüne yakın olabilmek için kent içinde ya da kente yakın konumlarda yer seçerken, bazı fabrikalar ürettiği ürünleri satabilmek amacıyla pazara yakın, bazı fabrikalar ise hammaddeye yakın konumda yer seçimi yapmışlardır. Ancak fabrikalar kent içinde ya da kente yakın konumda kurulmasa da, fabrikada çalşsacak işçilerin fabrikaya yakın olma istekleri ile birlikte fabrikalar etrafında yeni yerleşmeler oluşmaya başlamıştır. Bu yerleşmeler zamanla büyüyerek yeni kentler ortaya çıkmıştır.

Fabrikaların kurulması, oldukça fazla yeni istihdamın oluşmasına sebep olmuştur. Bu nedenle kırdan kente çok büyük oranlarda göçler yaşanmaya başlanmıştır. Sanayi Devrimi'nin başladığı Avrupa'da 14. yüzyılda nüfus artış hızı yaklaşık \%2,5 iken, 1850 - 1950 yılları arasında bu oran \%100'e çıkmıştır (Demir, 2018). Örneğin Manchester'ın nüfusu 1685 yılında 6000 kişi iken, 1760 yılında 40.000, 1801 yllında 72.000, 1851 yılında 300.000, 1900 yllında ise 600.000’e ulaştığı görülmektedir (Enlil, 2011).

Artan nüfusun yerleşimi için kent merkezlerinde yeterli konut bulunmaması nedeniyle tek ailelerin barındığı tek katlı konutlar yerlerini birden fazla ailenin yaşayabileceği apartmanlara bırakmıştır. Şehrin silütinde değişimlere neden olmuștur. Barınma talebinin artması ve işçi nüfusun kent merkezinde fazlalaşması ile birlikte zengin aileler kent merkezinden çeperlere doğru taşınmaya başlamış, merkezdeki konutlar işçi ailelere kiraya verilmeye başlanmıştır. Talebin yoğun olması, kiralarda artı̧̧a ve aynı konut içerisinde 60 - 70 kişiye varan yaşam koşullarına neden olmuştur. Kent sokaklarının dar, konutların birbirine yakın olması havasız, ışıksız ve sağlıksız yaşam koşullarını da beraberinde getirmiştir. Kolera, tifo ve tifüs gibi hastalıklar giderek yayılmaya başlamıştır. Bu dönemde yerel ve merkezi hükümetlerin karışmaması, tüm gelişimin özel sektöre bırakılması ile plansız gelişimin de bu sağlıksız koşullara büyük katkısı olmuştur. (Laissez faire, laissez passe - Bırakın yapsınlar, bırakın geçsinler yaklaşımı).

Yüksek gelir grubunun merkezden banliyölere doğru kaçmasıyla birlikte, kent merkezi etrafinda düşük gelir grubu, onun etrafinda orta gelir grubu ve en dışarıda da yüksek gelir grubu şeklinde bir yerleşim modeli oluşmuştur.

Kentlerde var olan sağlıksız koşullar giderek kent yaşamını tehdit eder hale gelmiştir. Sağlıksız koşullar pek çok hastalığın endüstri kentlerinde salgın hale dönüşmesine neden olarak, kentlerde sık sık kitlesel ölümlere yol açmıştır. Ancak, sanayi kentlerinde yaşanan salgın hastalıklar yalnızca emekçi kesim için tehlike doğurmayıp çevre sorunlarının niteliği gereği, burjuvaziyi de tehdit etmektedir. Nitekim bu salgınlar kentlerdeki endüstriyel üretim için artık bir sorun haline gelmiştir (Tekeli, 1980).

Bu dönemde ortaya çıkan Bahçe Kent, Güzel Kent, Geniş Kent (Broadacre City) gibi planlama yaklaşımları yer yer uygulansa da, soruna kalıcı çözüm getirememişlerdir. Sanayinin ve teknolojinin giderek gelişmesi ile ortaya çıkan yeni ürünler, yeni üretim modelleri 
ve yeni ulaşım seçenekleri ile birlikte, sanayinin işgücüne yakın olması gerekliliği yavaş yavaş ortadan kalkmaya başlamıştır. Özellikle kent içinde bulunan sanayi, atölye vb. imalat tesislerinin kentin çeperlerine doğru yönelmesi ve bunu takip eden banliyöleşme eğilimlerinin güç kazanması kritik bir değişim evresine işaret eder. Bu anlamda iç kentlerin çöküntü alanları olarak ortaya çımasında kentlerin çeperlerine doğru büyüme eğilimi, merkezdeki iş alanlarının bölgeyi terk etmesi, orta-üst sınıfların yeni alanlara göçü vb. birçok faktörün birlikte rol oynadığı görülmektedir. Çöküntü mahalleleri olarak ifade edilen bölgeler; büyüyen işsizliğe bağlı olarak yaşanan iş kayıpları, artan sosyal dışlanma, fiziksel çöküntüleşme ve yoksulluk ile kötüleşen yaşam standartları gibi istenmeyen sonuçlar ile kentsel mekânların insansızlaşmaya başlayan alanları olarak ortaya çıkmaktadır (Şen, 2012).

\section{Araştırma Sonuçları ve Tartışma}

\subsection{Kentsel Mekânlar}

\subsubsection{Kullanılmayan Kentsel Alanlar}

Kullanılmayan kentsel alan için yapılan tanımlar, genel olarak bu mekânların kökeniyle ve nasıl oluştukları ile ilgilidir. Ancak şehrin gelişimi sırasında boş tutulan araziler ile daha önce kullanılan ancak bir sebeple terkedilmiş araziler arasında önemli bir fark bulunmaktadır (Nefs, 2006).

Terkedilmiş alanlar çoğunlukla kentlerin tarihindeki çatlakları yansıtmaktadır, buna örnek olarak merkezdeki sanayinin çöküşü verilebilir. Önceki fonksiyonlarına bağlı olarak, terkedilmiş binalar kentin merkezinde, ya da bir nehir veya göl kenarındaki çekici bir noktada konumlanmıştır. Bu noktalar genel olarak fabrikaların yerleştiği noktalardır (Graner, 2017).

Günümüz kentlerinde dokunulmamıs binaların bir çoğu spekülasyon nedeniyle boş durumdadır, mal sahipleri mülkün değerinin artacağını ümit etmektedir. Piyasa fiyatları artana kadar binanın göz ardı edilmesi, binanın değerini otomatik olarak artırmamaktadır. Tam tersine, binanın kendi haline bırakılması, vandalizme maruz kalmasına ya da evsizler tarafından işgal edilmesine yol açabilmektedir. Kent bahçeleri gibi geçici kullanımlar, binanın ya da kentsel alanın imajının gelişmesinde olumlu bir etken olmaktadır. Binaların canlı görünmesi onları daha çekici kılmakta olup, kullanıcılar tarafından da bakımının yapılmasını sağlamaktadır. Geçici kullanıma yönelik resmi düzenlemeler, zaman çerçevesini ve fonksiyonu belirlemek için çok önemlidir, böylece geçici kullanımın durdurulması daha yumuşak bir süreçte gerçekleşir (Graner, 2017).

Kentteki boş alanlar, buralara yakın mahallelerin ihtiyaçlarına bağlı olarak farklı şekillerde kullanılabilir. Kent bahçeleri, kamusal ya da konut binaları olarak, mahallenin gelişimine katkıda bulunabilirler. Mahallenin daha önce karşılanmamış bir ihtiyacını karşılamak için kullanıldığında, bu boş alanlar, mahallenin yaşanabilirlik seviyesini de yükseltmektedir (Graner, 2017).

Kentin atıl bırakılmış olan bu mekânları kentlinin yaşamını etkileyecek, geliştirecek ve farklılaştıracak ortak bir yaşam alanına dönüştürülebilmektedir. Aktif bir sanayi ile etkin bir nüfusa sahip olan ancak sonrasında devre dışı kalan bu sanayi alanının kamuya fayda sağlayacak şekilde yeniden kazanılması ile terkedilmeye başlayan kent yeniden canlanabilmekte şehrin kalkınmasına ve tekrar tercih edilen bir yerleşim yeri olmasına da katkı sağlayabilmektedir. Yeniden bir cazibe merkezi haline gelen kent kalkınmaya ve yeniden yaşamaya başlamaktadır.

\subsubsection{Kamusal Alanlar}

Günümüzde halen kamusal alan ve kamusal mekân kavramlarının kesin bir tanımı yapılmamakla birlikte, geçmişte yapılmış bazı tanımlardan bahsedilebilmektedir. Jürgen Habermas, 1962 yılında yayınlanan "Kamusal Alanın Yapısal Dönüşümü: Burjuva Toplumunun Bir Kategorisi Üzerine Araştırmalar” adlı kitabında, kamusal alan tanımını ilk kez ele almıştır. Habermas kamusal alanı, özel şahısların, kendilerini ilgilendiren ortak bir mesele etrafında akıl yürüttükleri, rasyonel bir tartı̧̧ma içine girdikleri ve bu tartışmanın neticesinde o mesele hakkında ortak kanaati, kamuoyunu oluşturdukları araç, süreç ve mekânların tanımladığı hayat alanı olarak tanımlamaktadır.

"Kamusal alan, modern toplum kuramlarında, toplumun ortak yararını belirlemeye ve gerçekleştirmeye yönelik düşünce, söylem ve eylemlerin üretildiği ve geliştirildiği ortak toplumsal etkinlik alanına işaret etmek için kullanılan kavramdır” diyen Habermas, her türlü çıkardan arınmış, devlet otoritesinin baskısı ve buyruklarından, sermaye egemenliğinden bağımsız bir alan tanımlamaktadır (Güney, 2007).

Oscar Negt ve Alexander Kluge, Habermas'ın burjuva kamusallığına karşı çıkarak, kamusal alanı "mücadelenin savaş dışı yollarla karara bağlandı̆̆ı" proleter alan olarak tanımlarlar. Richard Sennett ise, "Kamusal İnsanın Çökü̈süu” baş̧ıklı kitabında kamusallaşma kavramını; özgünlük ve entelektüel derinlikle kamusal hayat ve özel hayat arasındaki dengesizliğin nedenlerini ve bu dengesizliğin yol açtı̆̆ı sorunları da irdeleyerek, batı Avrupa kentleri için, insanların belirli mekânlarda yoğun toplumsal ilişkiler kurma olanaklarına sahip olmaları olarak açıklamaktadır (Güney, 2007).

Kamusal alanların en önemli rollerinden biri kentsel gelişimi yönlendirmektir. Planlama uygulamasında, kentsel gelişmeler, piyasa mekanizması ile ya da bunun dışındaki kamusal alan stoğuyla kontrol edilebilmektedir. Kamusal alan, kamu yararı için, uygun yasal, yönetsel ve katılım mekanizmalarıyla kentsel gelişimi yönlendirmek için kullanılabilir. Kamusal alanın ikinci önemli rolü sağlıklı kentsel mekânlar yaratmaktır. Sağlıklı kentsel mekân yaratmak, sık kullanılan mekânlar ile nüfus yoğunluğu arasında dengeli bir ilişki sağlamak anlamına gelmektedir. Günümüz kentlerinde bu ilişki, mevcut yasalar ve düzenlemeler ile sağlanamamaktadır. Geniş alanlara 
ihtiyaç duyan spor, sağlık ve eğitim kompleksleri ve rekreasyon aktiviteleri için mekan yaratmak, kamusal alan stoğu olmayan bir kent için mümkün değildir. Bu nedenle, kamusal alan bu problemin çözümü için önemli rol oynamaktadır (Akkar, 1997: 29). Kamusal alanın kent planlamadaki üçüncü rolü ise sosyal destek sağlamaktır. Kamusal alan, sosyal sınıflar arasındaki gerilimi azaltmada önemlidir. Devlet, kamusal alan stoğunu kullanarak sık kullanılan kentsel mekânlar sağlayabilir (Akkar, 1997: 30).

Farklı ülkelerdeki farklı kentler, terkedilmiş alanlarla kendi özel durumlarına göre ilgilenmektedir. İsviçre'de, kent plancıları kenti içinde geliştirmeye odaklanmıştır. Buna göre gelişim için daha fazla alan kente katılmayacak, böylece doğa korunacaktır. Kentler, mevcut kentsel mekânda alan aramaya ve boş alan veya binalara odaklanmaya zorlanmaktadır. Burada kentler için iki seçenek bulunmaktadır: çok eski veya çok küçük binaların yıkılması ya da yeni bir kullanım kazandırılması (dönüştürme). Bu eylemler maliyet etkin yöntemlerdir, ancak mekânların tarihini ya da kimliğini kaybetmesi riskini barındırmaktadır. Başarılı bir dönüştürme örneği olarak Zürih’teki eski Toni Süt İşleme Binası’nın eğitim, kültür ve konut alanına dönüştürülmesi verilebilir.
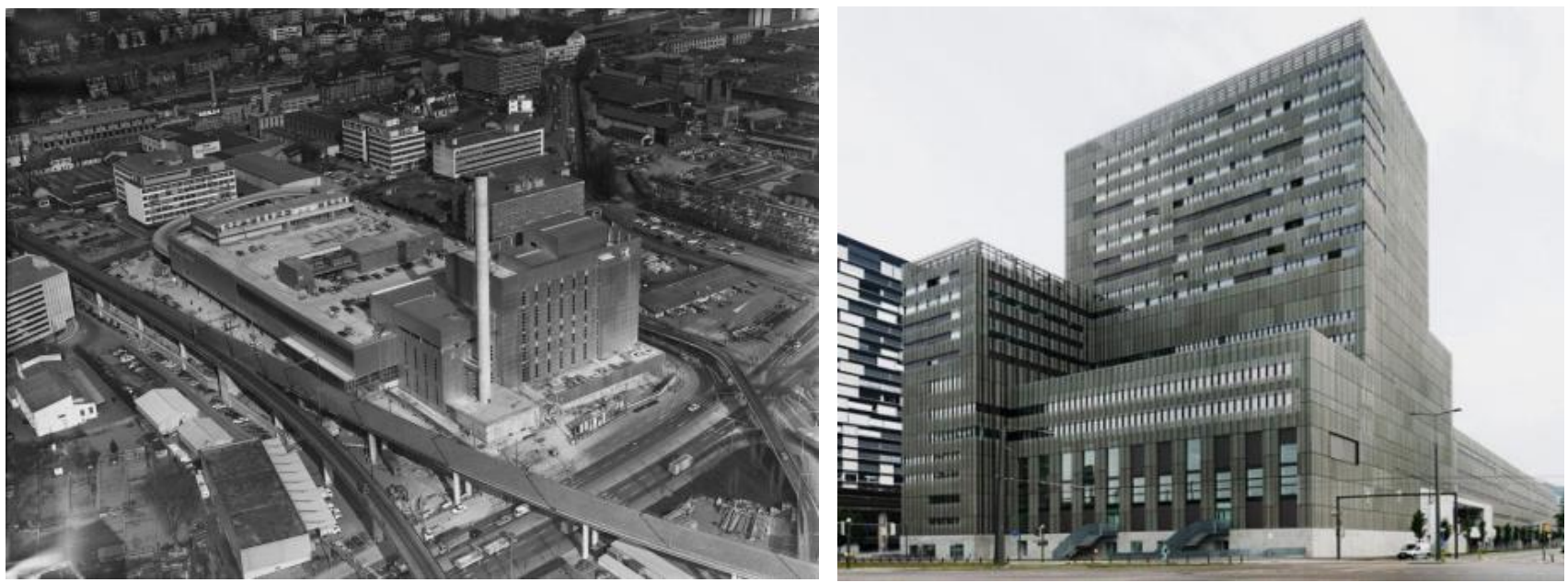

Şekil 1: Toni Süt İşleme Binası 1976 (sol) ve günümüzdeki görünümü (sağ)

Almanya, eski sanayi alanlarının yıkılmadan ve miraslarını kaybetmeden yeniden kullanımı açısından iyi örneklere sahiptir. Yerli halkın çalışma hayatının kömür madenciliğine sabitlendiği Ruhr bölgesi, ülkenin 200 yıldan fazla bir süre boyunca sanayi merkezi olmuştur. Sanayiler bölgeden çekilip fabrikalar kapandığında, birçok fabrika binası koruma altına alınmıştır. Bu hukuki işlemler, bölgenin kültürel mirasının ve geleneksel görünümünün korunmasında büyük rol oynamıştır. Bu arada birçok sanayi yapısı kültürel merkez ya da konut olarak kullanılmıştır. Aachen'daki Widra Areal, konut alanına dönüştürülen pek çok fabrikadan biridir. Duisburg'daki eski sanayi bölgesi ise peyzaj parkına dönüştürülmüştür.
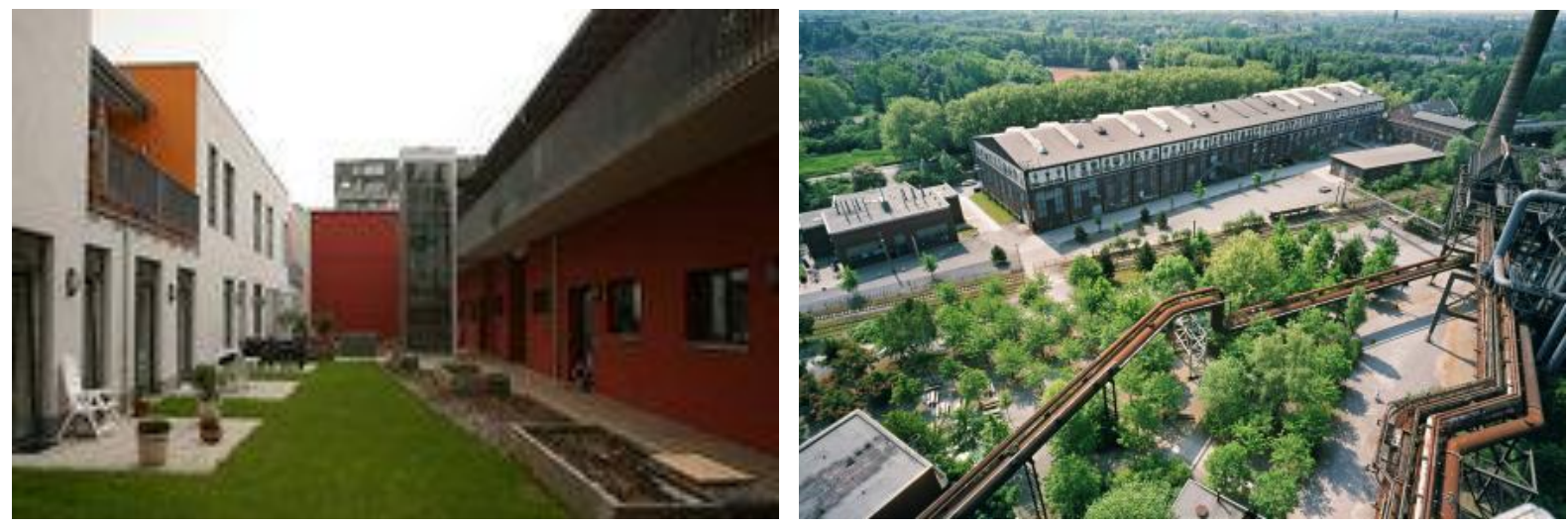

Şekil 2: Widra Areal Aachen (sol) ve Duisburg peyzaj parka (să̆)

Chicago'nun ticari kalbi olan Loop bölgesinde bulunan Millennium Park, 99.000 m2'lik bir alanı kaplamakta olup, devlet ve özel sektör ortaklığı ile yönetilmektedir. Yapımı için 475 milyon dolar harcanan ve 2017 yılında Chicago'nun ve Orta Batı Amerika'nın yıllık 25 milyon ziyaretçi ile en çok turist çeken noktası olan Millennium Park (Johnson, 2017), 1997 yılına kadar Illinois Central Railroad tarafindan tren rayı fabrikası olarak kullanılmaktaydı. Daniel Burnham, 1909 tarihli Chicago Planı'nda Illinois Central Railroad'un etrafında Büyük Park’1 (Grant Park) planlamıştır. 1997 yılında kent, tren rayları üzerinde üst kullanım hakkı elde edince, Büyük Park'ın kuzeybatı köşesinde rayların üzerine bir park yapılması kararlaştırılmıştır (Lewis, 2006). 1999 yılında kent konseyi, Frank Gehry tarafından park içerisinde bir konser ve gösteri alanı tasarlaması için görüştüğünü belirtmiştir. Gehry'nin projeye dâhil olması ile birlikte parkta modern temalar ve fütüristik öğeler tasarlanmaya başlanmıştır. 2004 yılında büyük bir tören ile park halka açılmıştır. 


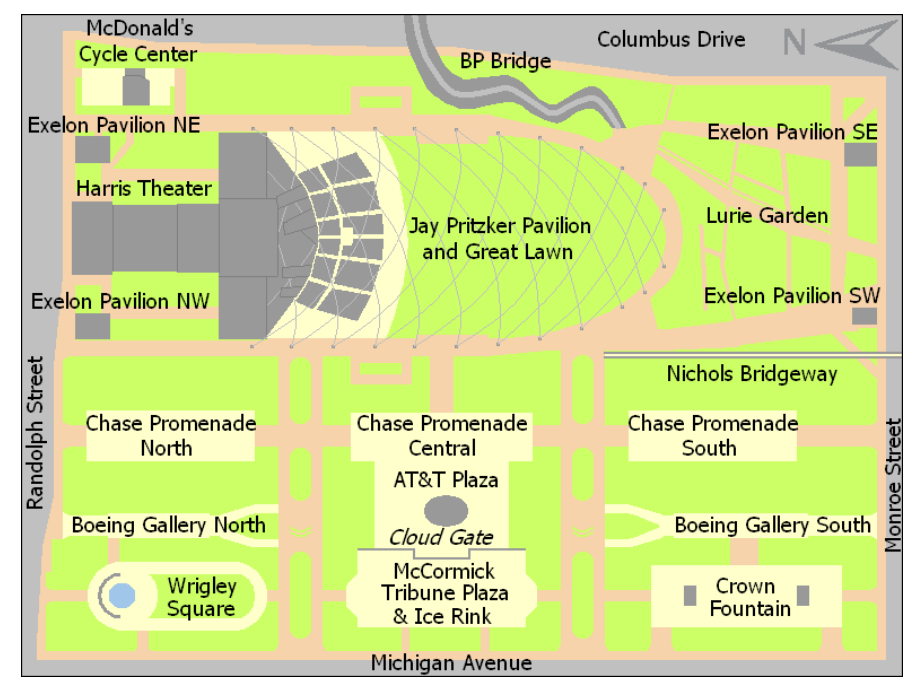

Şekil 3: Millennium Park haritası (www.wikipedia.org)
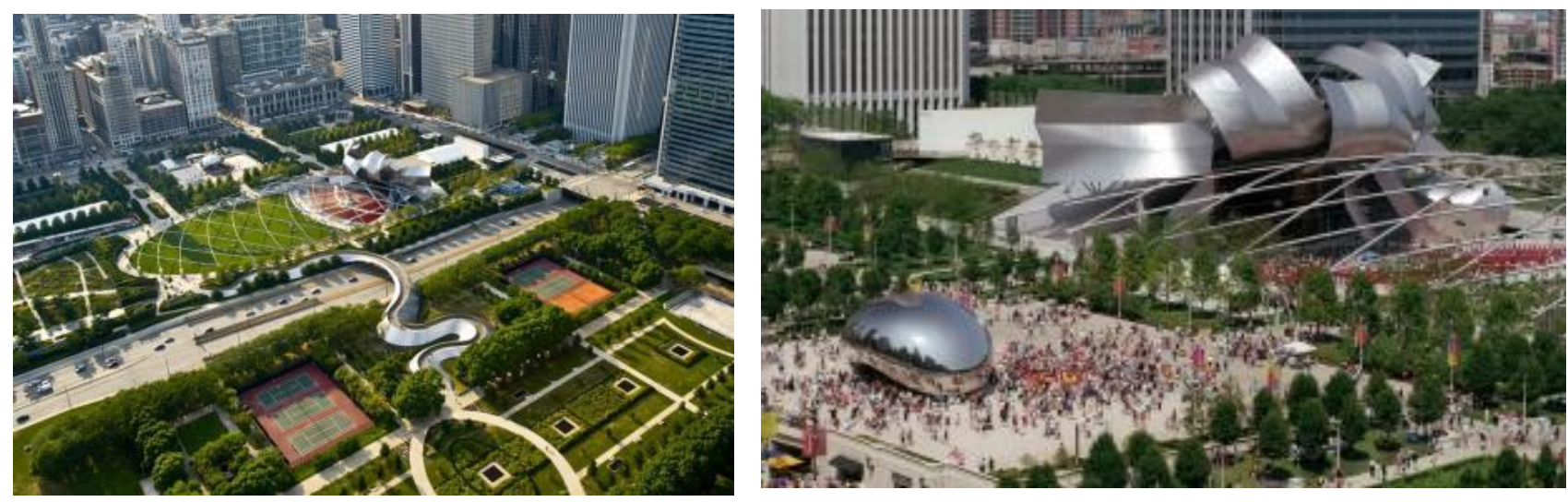

Şekil 4: Millennium Park'tan görünümler

Millennium Park’1 çevreleyen bölge, Chicago'daki en rağbet gören bölgelerden biri olmuştur. Forbes dergisi 2006 yılında parkın 60602 numaralı posta kodunu ülkedeki fiyat bakımından en sıcak bölge ilan etmiştir. Yine dergiye göre 2005 yılındaki 710.000 \$’lık konut fiyatları ile ülkedeki en pahalı posta kodu bölgelerinden biri olmuştur. Parkın açılması ile birlikte bölgede konut fiyatları metrekare başına 1076 \$’lık artış göstermiştir (Sharoff, 2006).

Yeniden kullanıma kazandırılan alanlar arasında özellikle İkinci Dünya Savaşı'ndan sonra müttefikler tarafından kurulan askeri alanlar bulunmaktadır. Bazıları kent merkezinde bulunan bu geniş alanlar, kamu kullanımına kapatılmış ve bu yüzden kentin geri kalanından yıllarca kopuk kalmıştır. Son yıllarda bu alanlar geliştirilmeye ve kente entegre edilmeye konu olmaktadır. Zorlanılan kısım ise kışlalara, eğitim alanlarına ve diğer yapılara fonksiyon bulunmasıdır. Bamberg şehri, kentteki farklı askeri binaların, şehrin sakinlerinin ihtiyaçlarını karşılayacak şekilde yeniden kullanımı için uğraş vermektedir. Bazı yapılar göçmenler için geçici barınak olarak kullanılmaktadır. Uzun dönemde ise amaç bu yapıları konut ve konutlara hizmet edecek okul ve mağazalara dönüştürmektir.

$\mathrm{Bu}$ örneklerle birlikte planlanmamış ve yatırım yapılmamış örnekler de mevcuttur. St. Louis'in kent çekirdeğinde, yoğun bir orman oluşmaya başladığı görülebilir. Hava fotoğraflarına bakıldığında, New York’taki Central Park’1 anımsatan, ancak daha çok ağaca sahip olan bir alandır. Alanı yoldan ayıran çitlerin yanından yürürken, kuş sesleri insana halen şehirde olduğunu unutturmaktadır. Bu orman Pruitt-Igoe konut projesinin de içinde olduğu terkedilmiş alanlarda ortaya çıkmıştır. Bu parseller şu anda görsel çekicilik yaratan, kent doğası ile etkileşim kurma imkânı veren, kent içi ısıyı azaltan ve fazla yağmur sularını tutan yeni ekolojilere ev sahipliği yapmaktadır (Nemeth, Langhorst 2014).

Bu örnekler kentten izole edilmiş örnekler değildir. Philadelphia, Detroit ve Chicago'da pek çok boş arsa, komşuların suladığı, temizlediği veya yalnızca günlük sohbetler ettiği, ayçiçekleri, kök sebzeler ve mısırlarla dolu geçici hobi bahçelerine dönüşmüştür. California Sebastopol'da bir otopark alanı haftada iki kez her çeşit organik yiyeceğin satıldığı bir pazar alanına dönüşmektedir (Schwarz, 2010).

İlkbaharda bir hafta sonu, uçuşlara kapatılmış ve terkedilmiş Berlin Tempelhof havaalanı yeniden ve kendi kendine bir enerji ile dolmuştur: binlerce insan bu büyük alanda kendilerine ait bir yer bulmuştur; piknik yapanlar, frizbi oynayanlar, spontane futbol maçları, müzik çalan amatör müzisyenler, mangal yapan aileler, kitap okuyan öğrenciler, sebze ve çiçek yetiştiren insanlar ve uçurtma uçuran 
çocuklar. Bu aktivitelerin hiç biri geleneksel algı ile planlanmamış ya da programlanmamıştır, tam tersine bu aktiviteler, belediyenin bütçe kısıtlamaları ve yüksek inşaat maliyetleri nedeniyle alanı geliştirememesinden kaynaklanan plansızlıktan doğmuştur.

Resmi olarak 1923 yılında havaalanı olarak kullanılmaya başlanan Tempelhof Havaalanı, 1926 yılında kurulan Lufthansa Havayolları'na ev sahipliği yapmıştır. Eski terminal binası 1927 yılında yapılmıştır. Daha sonra Nazilerin kentin yönetimini ele geçirmesiyle birlikte, Adolf Hitler'in Berlin'i dünya başkenti “Germania” yapma hayalleri doğrultusunda 1934 yılında terminal binasının yenilenmesi emri verilmiştir. 1936 ve 1941 yılları arasında inşa edilen terminal binası 1,2 km'lik bir cepheye sahiptir ve İngiliz mimar Sir Norman Foster tarafından “tüm havaalanlarının anası” olarak nitelendirilmiştir. Hangarlar ile birlikte terminal 300.000 m2'lik bir alan kaplamaktadir.
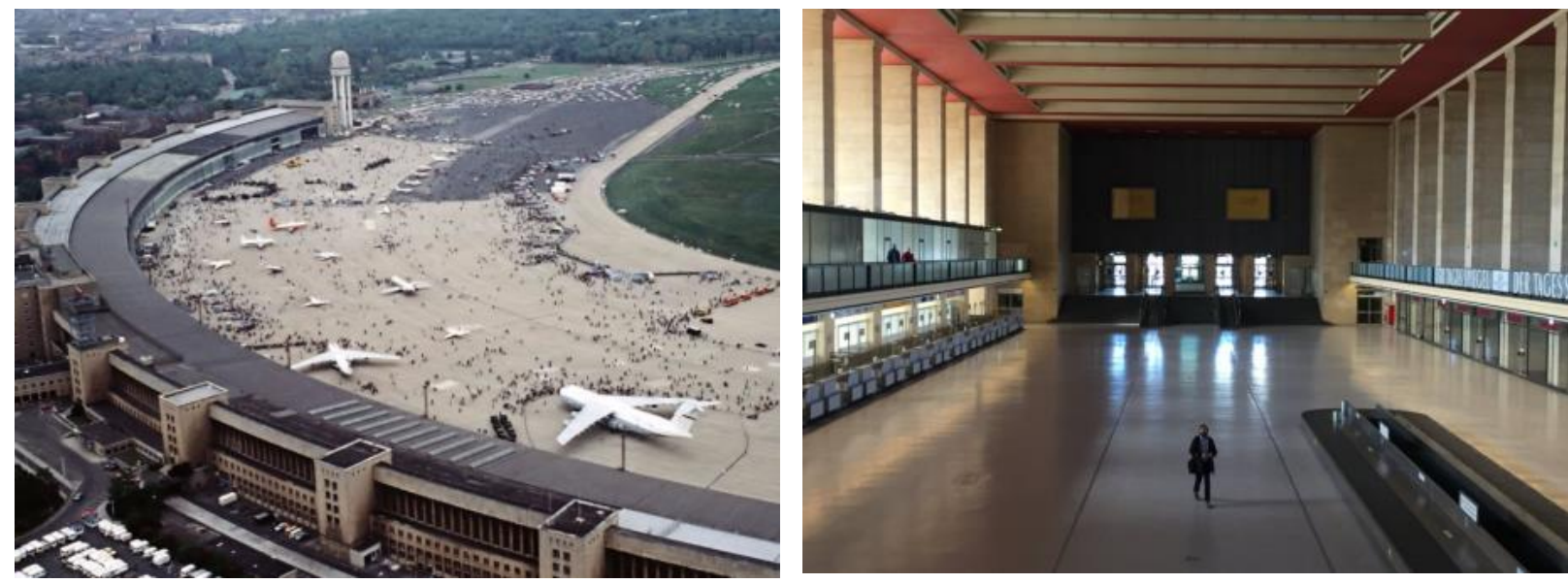

Şekil 5: Berlin Tempelhof Havalimanı'ndan görünümler

Tempelhof Havaalanı 2008 yılında uçuşlara ve halka kapatılmıştır. İnsanların spontane bir şekilde havaalanını park olarak kullanmaya başlamasıyla birlikte, 2009 yılında hükümet de burayı park alanı olarak geliştirmeye başlamıştır. 2014 yılında yapılan bir referandumda halk buranın park olarak kullanılmasını istemiştir. 2015 yılı itibariyle havaalanının hangar binaları, genel olarak Suriye, Irak ve Afganistan'dan gelen göçmenler için barınak olarak kullanılmaya başlanmıştır. Başlangıçta 1200 civarı olan göçmen sayısı 2018 ortalarına doğru 400'e kadar gerilemiştir. Günümüzde Tempelhof Havaalanı, uçurtma uçuranlara, patencilere, sanatçılara, bisikletçilere, sporculara, dansçılara ve müzisyenlere ev sahipliği yapmaktadır. 2018 Mayıs ayında Formula E yarışı burada düzenlenmiştir.

\section{Sonuç}

Tüm dünya kentlerinde geçmişte belli bir fonksiyona sahip olup, zamanla işlevini kaybetmesi ile terkedilmiş yapılar ve mekânlar bulunmaktadır. Bunların büyük bir kısmı inşa edildiği ya da kullanıldığ tarihte kentin dışında yer almış, ancak zaman içinde kentin gelişimi ve büyümesiyle kentin içinde kalmıştır. Kentin içinde yer alan ve bu kullanılmayan yapı ve alanların yeniden değerlendirilmesi gerekliliği ortaya çıkmıştır.

Bu yapı ve alanlar, kamu müdahaleleri ile yeniden değerlendirildiği gibi, halk tarafından da zaman zaman plansız şekilde kullanılmaya ve değerlendirilmeye başlanmıştır. Ancak kim tarafından değerlendirilirse değerlendirilsin, amaç bu yapı ve mekânları kamu kullanımına kazandırmaktır. Başka bir deyişle bu yapı ve mekânların kente yeniden kazandırılmasında insan faktörü en önemli unsurdur.

$\mathrm{Bu}$ alanları değerlendirirken, genel olarak kentin eksikliğini hissettiği fonksiyonları veya mevcudun yetersiz kaldığı fonksiyonları da göz önünde bulundurmak gerekmektedir. Halkın kendi değerlendirmesinde ise genellikle kişilerin o mekânda ne olmasını istediği ya da o mekânda ne yapmak istediği ön plana çıkmaktadır. Kamunun değerlendirmesi seçeneğinde, kamunun son kullanıcı olan halkın da görüşlerini alması, bu mekânların etkili kullanımının sağlanmasında oldukça önemlidir. Böylece kent halkı daha mutlu ve huzurlu hissedecek ve kentsel alan kalitesinin artırılmasına katkı sağlayacağı gibi ekolojik dengenin korunmasına katkı gibi pek çok faydayı da sağlayacaktır.

Ülkemizde de bu tarz örneklere rastlanmaktadır. Özellikle İstanbul gibi nüfusun çok yoğun olduğu iş, konut ve yaşam alanlarının birbirine karıştığı ve bu fonksiyonların artan ihtiyaca cevap verebilmek için şehirn içinde kendilerine zorlukla yer bulduğu bir şehirde. Özellikle büyük şehirlerde, kentin içinde kalan bu mekanların arazi değerlerinin yüksek olması sebebiyle, yeniden değerlendirme sırasında bu mekanlar, rant kaygısına yenik düşmektedir. Bu noktada yeni işlevlendirme aşamasında önceden de bahsedildiği gibi fonksiyon seçiminde kamu tarafından tüm halkın kullanımında olacak bir takım çözümlere gidilmesi gerekliliği tekrar ortaya çıkmaktadır. Örnek olarak İstanbul Mecidiyeköy’deki koruma altında olan eski Tekel Likör Fabrikası ve bitişiğindeki Ali Sami Yen Stadı'nın yıkılarak yerine konut, ofis ve alışveriş merkezi yapılması verilebilir. Bir diğer örnek olarak henüz işlevi net olarak belirlenmemekle birlikte İstanbul'daki Haydarpaşa Tren Garı'nın, Marmaray'ın tamamlanması ve hattın başka istasyonlara bağlanması sonucu fonksiyonunu yitirmesi ile birlikte atıl kalması. Medyada çıkan kimi haberlere göre bu yapı müze olarak değerlendirilecek, kimi haberlere göre ise yapı yıkılarak yerine otel ve rezidans yapılacaktır. Bu noktada daha önce belirtildiği gibi şehirin kimliğinin bir parçasını oluşturan tarihi değere sahip yapıların yıkılmadan uygun bir işlev ile halkla buluşturulması en uygun çözümü oluşturacaktır. 
İstanbul'daki bir başka örnek ise yeni İstanbul Havalimanı ile birlikte mevcut Atatürk Havalimanı'nın fonksiyonunu yitirecek olmasıdır. 13 milyon metrekare alana sahip Atatürk Havalimanı için şu ana kadar yapılan açıklamalar, yapılarının fuar alanı olarak kullanılmaya devam edeceği, kalan kısmının ise yapılaşmaya açılmayarak millet bahçesi olarak değerlendirileceği yönündedir.

Dünya şehirleriyle ilgili istatistiksel raporlar yayınlayan World Cities Culture'ın son raporunda (2019) İstanbul, sahip olduğu \%2,2'lik yeşil alanı ile değerlendirmeye giren 37 dünya kenti arasında son sırada yer almaktadır (Url-4). Büyükşehir Belediyesi yetkilileri, kişi başına düşen kent içi yeşil alan oranının $8,41 \mathrm{~m}^{2}$ olduğunu belirtirken, Çevre ve Şehircilik Bakanlığı verilerine göre İstanbul'da kişi başına $7,57 \mathrm{~m}^{2}$ yeşil alan düşmektedir. Kişi başı $15 \mathrm{~m}^{2}$ yeşil alan olan yasal sınırın altında kalan 30 ilçenin 6'sı $1 \mathrm{~m}^{2}, 21$ 'i ise $8 \mathrm{~m}^{2}$ 'nin altında yeşil alana sahiptir. Bazı ilçelerde bu miktar \%1'in bile altındadır (Url-5).

İstanbul halkı giderek büyüyen ve yaşamanın giderek zorlaştığı bu megakentte nefes alacak mekânlara ihtiyaç duymaktadır. Özellikle Mecidiyeköy'deki stadın ve fabrikanın yeniden değerlendirileceği haberleri duyulduğunda, halkın büyük çoğunluğu burada bir kent parkının yapılmasını istediklerini dile getirmiştir. Arazi üzerinde yapılaşmanın taban oturumu her ne kadar kısıtlı tutulsa da, bırakılan yeşil alan kentin ihtiyacını karşılamaktan oldukça uzaktır.

Ortak yaşama yeniden kazandırılacak alanların değerlendirmesi yapılırken mutlaka insan faktörü göz önünde bulundurulmalıdır. Kentin ihtiyaçları, son kullanıcısı olan halkın ihtiyaçları çok iyi analiz edilmeli, halkın da bu konudaki görüşleri dinlenmeli ve dikkate alınmalıdır. Daha yaşanabilir, sağlıklı kentlerin elde edilmesinde bu çözüm büyük katkılar sağlayacaktır.

\section{Kaynakça}

Adedeji, O.H., 2011. Human Settlement and Development Lecture Notes, UNAAB, Abeokuta, Nijerya.

Akkar, M., 1997. "Kent Planlamasında Kamu Arazileri”, Özelleştirme ve Kamu Arazileri içinde, ed. Serdar Karaduman, Gülten Kubin, Ankara: TMMOB Şehir Plancıları Odası Yayınları.

Altuntaş, N., 1997. "Siyasal Katılımda Bir Değişim Modeli: Gecekondularda Araçsal Katılımdan Özerk Katılıma Dönüşüm”, Yüksek Lisans Tezi, Hacettepe Üniversitesi Sosyal Bilimler Enstitüsü, Ankara.

Baykara, T., 2002. "Sosyal yapı ve Şehir Hayatı", Yeni Türkiye Dergisi, Mayıs-Haziran 2002

Demir, E., 2018. “Sanayi Devrimi ve Kent”, Kent Sosyolojisi Ders Notları, Ankara Üniversitesi, Ankara.

Dinçer, Y., 1999. "Kent, Kentleşme ve Kent Planlaması, Sivil Toplum İçin Kent, Siyaset ve Demokrasi Seminerleri”, Demokrasi Kitaplı̆ğ-WALD Yayınları, İstanbul.

Enlil, Z., 2011. Kent ve Planlama Tarihi Ders Notları, Yıldız Teknik Üniversitesi, İstanbul.

Graner, A., 2017. "Why should we deal with abandoned urban spaces?", https://www.urbanet.info/abandoned-urban-spaces/

Güney, Z., 2007. "Kamusal Alan Nedir? Kamusal Mekan Nedir?” www.arkitera.com

Johnson, S., 2017. "Millennium Park is new top Midwest visitor destination, high-tech count finds", www.chicagotribune.com

Lewis, M.J., 2006. Gazete yazis1, The New York Times

Nefs, M., 2006. "Unused urban space: conservation or transformation? Polemics about the future of urban wastelands and abandoned buildings". City \& Time 2 (1): 4. [online] URL: http://www.ct.ceci-br.org

Nemeth, J., Langhorst, J., 2014. "Rethinking urban transformation: Temporary uses for vacant land", Cities, vol.40, 143-150.

Özcan, U., Erol, İ.,2018, "Sürdürülebilir Yerel Planlamada Coğrafi Bilgi Sistemi”, International Journal Of Social And Humanities Sciences (ISSN: 2602-3288), Say1:2, s:85

Özcan, U., Dağdeviren, Z.S.,(2019), "The Revitalization Of Urban Ruined Regions By Sustainable Design Thought Bronx / NY Sample", İçinde: Kaya, Latif Gürkan (Ed.), 2019, Research \& Reviews in Architecture, Planning and Design - Summer, 2019 (ISBN: 978-605-7852-92-2), Gece Kitaplığı Yayınevi, İstanbul.

Özcan, U., Caştur, Ş.N.,(2019), " Spor Kompleksi Yapılarının Kültür Yapılarına Dönüşümü// Avrupa Örneği", İçinde: Atik, Atilla, Kaya, Latif Gürkan ve Abbasova, Sehla (Ed.), 2019, Mimarlık, Planlama ve Tasarım Alanında Araştırma ve Değerlendirmeler - Mart 2019 (ISBN: 978-605-7631-54-1), Gece Kitaplığı Yayınevi, İstanbul.

Öztürk, T., Ürük, Z. F, Özel, Y., Uzgören, G., "Mekansal Elverişlilik ve Fiziksel Çevre Kalitesi Bağlamında Mekânsal Kalite Analizi”, 2. Ulusal İç Mimari Tasarım Sempozyumu 2018, 06-07 Aralık 2018, Trabzon

Schwarz, T., 2010.” Temporary services for shrinking cities", Cleveland urban design collective, Kent State University, USA.

Sharoff, R., 2006. "How a Park Changed a Chicago Neighborhood", The New York Times.

Sjoberg, G., 2002. "Sanayi Öncesi Kenti”, Ayten Alkan, Bülent Duru (Der. ve Çev.), s. 37-54, 20. Yüzyıl Kenti, İmge Yayınevi, Ankara.

Şen, B., 2012. "Metropol Kent Merkezlerinde Çöküntüleşme Eğilimleri: İstanbul Eminönü - Süleymaniye Bölgesi Örneği”, Süleyman Demirel Üniversitesi İktisadi ve İdari Bilimler Fakültesi Dergisi, Vol. 17, Sayı 2, s. 293-323.

Tekeli, İ., 1980. “Türkiye'de Kent Planlamasının Tarihsel Kökleri, Türkiye’de İmar Planlaması”, Mimarlık Fakültesi Yayınları, ODTÜ, Ankara.

Uzgören, G., Öztürk, T., Ürük, Z. F, Özel, Y., "Kamusal Alanda Kentsel İç Mekanları Placemaking Süreci Üzerinden Okumak: "Project for Public Spaces” Derneğinin Çalışmalarının İncelenmesi”, 2. Ulusal İç Mimari Tasarım Sempozyumu 2018, 06-07 Aralık 2018, Trabzon

Ürük, Z. F, İslamoğlu, K.A.K (2019). Yüksek Binalarda Enerji ve Sertifikasyon Sistemleri İlişkisi., Kaya, L.G., Abbasova S. (Ed.), Mimarlık, Planlama ve Tasarım Alanında Araştırma ve Değerlendirmeler., (ss.59-68). Gece Akademi, Ankara Print ISBN 978605-7631-54-1

Ürük, Z. F, İslamoğlu, K.A.K. “Sürdürülebilir Konutlar ve Sertifikasyon Sistemleri”, 2. Uluslararası Mühendislik ve Mimarlık Kongresi ENAR 2018, 14-16 Kasım 2018, Alanya, Türkiye 
Ürük, Z. F, İslamoğlu, K.A.K. "Relation of Sustainable Energy and Certification Systems In High-Rise”, 2. Uluslararası Multidisipliner Çalışmalar ve Yenilikçi Teknolojiler Sempozyumu, 19-20-21 Ekim 2018,Kızılcahamam Ankara, Türkiye

Ürük, Z. F, İslamoğlu, K.A.K, Erol, İ. "Raylı Sistem İstasyonlarının Sürdürülebilirlik Kapsamında Mekânsal Dönüşümü”, 1. Uluslararası Mimarlık Sempozyumu 2018, 04-06 Ekim 2018, Dicle Üniversitesi, Diyarbakır, Türkiye

Ürük, Z. F, İslamoğlu, K.A.K. "Breeam, Leed Ve DGNB Yeşil Bina Sertifikasyon Sistemlerinin Standart Bir Konutta Karşılaştırılması", European Journal of Science and Technology, say1:15, Mart 2019, ss. 143-154, ISSN NO: 2148-2683, DOI : 10.31590/ejosat.512291

Url-1: https://courses.lumenlearning.com/boundless-sociology/chapter/urbanization-and-the-development-of-cities/

Url-2: http://www.forbes.com

Url-3: https://www.arkitektuel.com/parc-de-la-vilette/

Url-4: http://www.worldcitiescultureforum.com/data/of-public-green-space-parks-and-gardens

Url-5: https://www.gercekgundem.com/istanbul/64816/istanbulda-hangi-ilce-ne-kadar-yesil 